JURNAL PENGABDI - ISSN: 2620-4665 (p) / ISSN: 2620-4673 (e)

APRIL 2021, Volume 4 Nomor 1

Website: http://jurnal.untan.ac.id/index.php/JPLP2KM

\title{
Pembelajaran Edukatif yang Asyik di Masa Pandemi
}

\author{
Ria Asep Sumarni ${ }^{1)}$, Siti Ayu Kumala ${ }^{2)}$, Fita Widiyatun ${ }^{3)}$ \\ ${ }^{1 / 2) 3)}$ Program Studi Teknik Informatika,Universitas Indraprasta PGRI \\ Corresponding Author: Ria Asep Sumarni, riaasepsumarni@gmail.com
}

\begin{abstract}
Abstrak: Permainan edukatif yang asyik salah satunya adalah kartu domino dan Uno Stacko. Kedua permainan ini merupakan permainan yang sangat mudah untuk dipelajari dan dimainkan. Pada umumnya, kartu domino berisikan dua bagian yang dipisahkan oleh garis tengah dan mempunyai beberapa jumlah lingkaran yang menunjukkan angka pada kartu tersebut. Tujuan dari pengabdian masyarakat ini adalah mengenalkan permainan kartu domino dan Uno Stacko dengan materi fisika. Di setiap kartu domino mempunyai pasangan yang berisi tentang materi pelajaran, dalam permainan ini kita bermain untuk mencari pasangan dengan materi yang sama. Sedangkan pada Uno Stacko dilengkapi dengan pertanyaan materi pelajaran, dimana saat kita memainkannya kita harus menjawab pertanyaan pada balok Uno Stacko tersebut. Metode Pengabdian masyarakat ini adalah memberi pelatihan pengenalan, pembuatan dan cara menggunakan permainan edukatif melalui webinar kepada MGMP Fisika Kabupaten Lebak. Hasil dari pengabdian kepada masyarakat ini adalah para peserta webinar pelatihan dapat membuat sendiri dan memberikan pengalaman permainan edukatif kepada para siswa meskipun dalam situasi pandemi Covid 19 yang mengharuskan pembelajaran secara daring. Adanya permainan edukatif yang asyik ini bisa dilakukan di rumah dengan bermain sambil belajar. Sehingga pembelajaran akan lebih menarik dan tidak membosankan.
\end{abstract}

Kata Kunci: permainan, edukatif, kartu domino, Uno Stacko.

Abstract: One of the fun educational games is domino cards and Uno Stacko. Both of these games are very easy to learn and play. In general, dominoes contain two halves separated by a center line and have a number of circles that indicate the numbers on the card. The goal of this community service is to introduce the domino card game and Uno Stacko with physics material. In each domino card has a pair that contains the subject matter, in this game we play to find a partner with the same material. Whereas Uno Stacko is equipped with subject matter questions, where when we play it we have to answer the questions on the Uno Stacko block. This community service method is to provide training in introducing, making and how to use educational games through webinars to the MGMP Fisika Kabupaten Lebak. The result of this community service is that the training webinar participants can create their own and provide educational game experiences to students even though in the Covid 19 pandemic situation which requires online learning. The existence of this fun educational game can be done at home by playing while learning. So that learning will be more interesting and not boring.

Keywords: game, educational, domino card, Uno Stacko.

\section{Pendahuluan}

Pendidikan sangat memegang penting dalam kehidupan seseorang maupun suatu bangsa, kemajuan pembangunan di suatu negara, baik lahir maupun bathin dapat dicapai melalui pendidikan yang terarah dan berkesinambungan. Dengan pendidikan yang baik, akan menciptakan manusia yang cerdas, terampil, berwawasan luas, disiplin, beriman, bertaqwa serta bertanggung jawab di dalam kehidupan. Selain itu juga dapat meningkatkan pembangunan di sektor ekonomi akan berkembang pesat, perkembangan ilmu pengetahuan dan teknologi akan maju dan tidak tertinggal dari negara lain. Namun pada masa ini dunia sedang

Submitted: 18.02.2021, Revised: 08.04.2021, Accepted: 13.04.2021 
dilanda musibah yaitu merebaknya virus corona (Covid 19) yang menginfeksi hampir 24 juta orang, hal ini membuat hampir semua bidang ekonomi, pembangunan maupun pendidikan terganggu.

Pendidikan dapat diperoleh dengan berbagai cara, formal maupun informal. Formal yaitu lewat institusi seperti sekolah, sedangkan informal dapat diperoleh dari keluarga dan lingkungannya. Intinya, pendidikan itu adalah tidak terbatas waktu dan tempat kita dalam memperoleh ilmu, tempat dan waktu dalam transfer ilmu. Pendidikan tidak terlepas dari proses transfer ilmu, baik dirasakan secara langsung, maupun tidak langsung. Namun pada masa pandemi covid 19 seperti ini, telah banyak perubahan dalam proses pembelajaran, salah satunya penggunaan pembelajaran secara daring dengan melibatkan banyak aplikasi-aplikasi yang dapat membantu dalam proses pembelajaran.

Media pembelajaran merupakan sarana penyalur pesan materi pelajaran yang disampaikan guru agar siswa mudah menerima materi yang sudah disampaikan (Ramadhani et al., 2016). Media pembelajaran yang efektif dan efisien menentukan apakah informasi pembelajaran yang disampaikan mempengaruhi hasil belajar siswa (Azmi \& Rukun, 20). Pembelajaran edukatif yang asyik dimasa pandemik dirasa sangat dibutuhkan untuk membatu siswa dalam proses pembelajaran. selain aplikasi-aplikasi yang membantu proses dari, ada banyak sekali pembelajaran edukatif salah satunya pemanfaat media bermain yang dapat digunakan sebagai media untuk membantu dalam mentransfer ilmu di masa Pandemi ini. Sebagai contoh media permainan kartu, permainan ini dapat meningkatkan pemahaman dan pengetahuan dalam suatu bidang studi pembelajaran. Pengembangan media permainan matematika dengan kartu domino sudah pernah dikembangkan oleh (Fairosa et al., 2018). Kartu domino merupakan permainan yang sangat mudah untuk dipelajari dan dimainkan (Widiyatun et al., 2020). Penggunaan media permainan kartu domino dapat meningkatkan prestasi belajar siswa (Jayanti \& Azmi, n.d.).

Permaianan kartu domino telah banyak diteliti sebagai media pembelajaran di kelas. Salah satunya adalah pembelajaran kartu domino dikembangkan dan dipadukan dengan materi fisika (domika) sehingga dapat membantu proses belajar peserta didik dengan nuansa menyenangkan, merasa tidak bosan, dan bersemangat dalam mengerjakan soal (Wiyono et al., 2020). Selain kartu domino juga terdapat permainan menggunakan Uno Stacko sebagai media pembelajaran yang berguna untuk memahami seberapa besar pengetahuan dan prestasi anak dalam mengenal lambang bilangan sesuai pemikirannya dalam mengkonstruksi lambang bilangan tersebut tanpa guru menyalahkan hasil pemikiran anak (Gustiasih \& Widajati, 2016). engabdian masyarakat ini, dilakukan dengan membuat suatu media pembelajaran dengan permainan kartu untuk pelajaran fisika pada materi besaran dan satuan. Besaran yang digunakan adalah semua besaran, baik besaran pokok maupun besaran turunan beserta dengan satuannya. Fisika merupakan salah satu mata pelajaran pada ilmu alam yang termasuk ke dalam golongan yang sulit untuk dipahami dan diselesaiakan oleh siswa. Dimasa pandemi seperti ini, pembelajaran yang digunakan hampir semuanya menggunakan Daring. Sebelum adanya Covid 19 sudah banyak siswa yang mengeluh tentang sulitnya memahami konsep-konsep, maupun dalam mengerjakan soal fisika. Karena hal tersebut, perlu dibuatkan suatu media yang dapat membantu siswa dalam memahami dan belajar materi fisika di masa pandemik Covid 19 ini.

Tujuan dari pengabdian masyarakat ini adalah mengenalkan media permainan fisika berbasis kartu domino dan Uno Stacko. Media pembelajaran ini dapat menambah pemahaman dan pengetahuan bagi guru dalam menyampaikan materi fisika kepada siswa. Guru lebih banyak berperan sebagai informan bagi siswa. Metode pembelajaran yang sering terjadi adalah materi-materi yang dirasa penting dicatat oleh guru di papan tulis. Siswa cenderung pasif dalam pembelajaran karena interaksi antara guru dengan siswa hampir tidak ada (Nugroho et al., 
2013). Dengan permainan yang menyenangkan diharapkan bisa membantu proses pembelajaran edukatif yang asyik dimasa pandemic covid 19. Media pembelajaran digunakan untuk menyampaikan materi pembelajaran dengan harapan dapat merangsang perhatian dan minat peserta didik dalam belajar (Putri \& Airlanda, 2020). Penggunaan permainan kartu domino dan Uno Stacko dalam pembelajaran fisika dapat menjadi media pembelajaran yang lebih interaktif di masa pandemik. Oleh karena itu, perlu dilakukan kegiaatan pengabdian masyarakat kepada Guru tentang media pembelajaran asyik ini. Guru diberikan pembekalan pengetahuan dan kemampuan dalam memilih dan mengembangkan media pembelajaran agar dapat mempermudah peserta didik dalam menerima materi pembelajaran (Fadli et al., 2017).

\section{Metodologi}

Metode yang digunakan adalah metode pelatihan dan pendampingan serta diskusi secara daring dengan aplikasi Zoom. Pelatihan dilakukan dengan cara memperkenalkan dan mensosialisasikan pembelajaran edukatif yang asyik untuk digunakan dalam pembelajaran di massa pendemi. Materi yang diberikan saat pelatihan meliputi contoh media pembelajaran menggunakan permainan kartu domino dan Uno Stacko. Dengan menggunakan video tutorial dan aplikasi zoom yang dilakukan bersama guru-guru MGMP Fisika Kabupaten Lebak Banten. Beberapa tahapan yang dilakukan oleh tim dalam kegitan pengabdian masyarakat adalah sebagai berikut:

\section{A. Membuat Panduan Pembuatan Permainan Edukatif.}

Dalam kegiatan ini tim membuat turorial tahapan-tahapam dalam pembuatan dan penggunaan permainan edukatif ini.

\section{B. Pemaparan Materi Permainan Edukatif.}

Setelah tutorial dibuat, tim menampilkan tersebut pada saat kegiatan melalui zoom, agar peserta dapat melihat dan menyimak tahapan-tahapan dan penggunaan permainan edukatif ini.

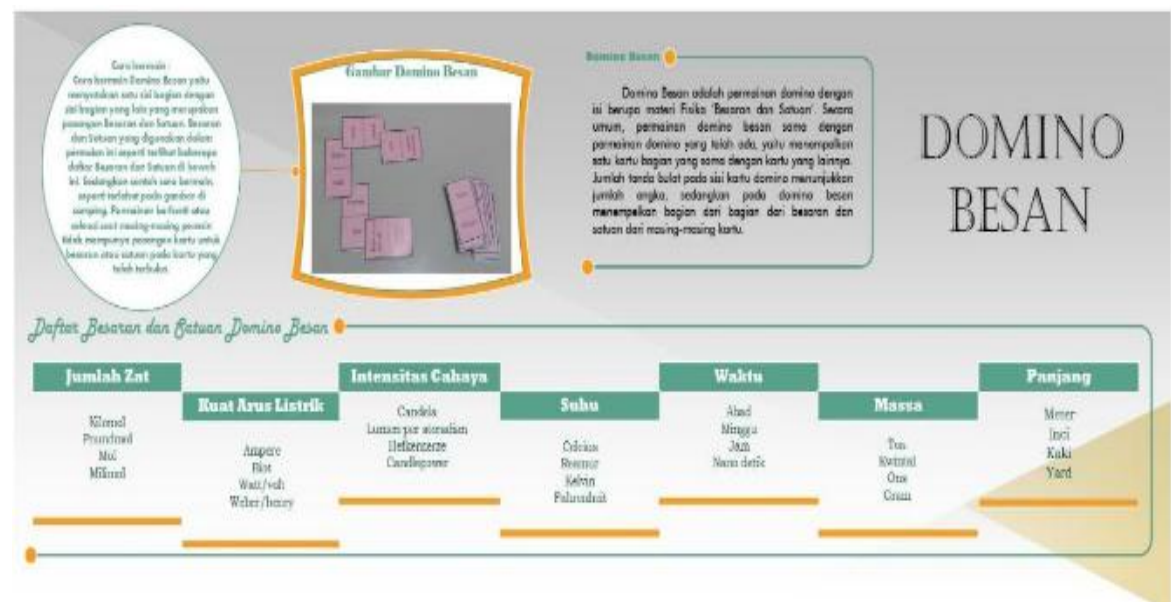

Gambar 1. Tata Cara penggunaan Kartu Domino Besaran dan Satuan

\section{Melakukan Pembuatan Permainan Edukatif.}

Sebelum kegiatan pengabdian masyarakat ini dilakukan, peserta terlebih dahulu diberikan informasi untuk menyiapkan alat tulis, lem, kartu domino dan Uno Stacko stacko. Sehingga 
setelah tahapan melihat tutorial, para peserta dimohon untuk membuat permainan edukatif tersebut sesuai dengan materi yang peserta inginkan.

\section{Monitoring Penerapan Hasil Pelatihan Terhadap Masyarakat.}

Pada tahapan ini, tim melakukan monitoring dan diskusi bagi para peserta yang masih bingung dalam pembuatan permaianan edukatif ini. Tim membantu mengarahkan dan berdiskusi dalam membuat permainan edukatif ini.

Empat kegiatan di atas juga merupakan solusi tindakan untuk menyelesaikan permasalahan yang sedang dihadapi mitra. Dimana pada saat pelaksanaan kegiatan pengabdian masyarakat ini, beberapa peserta menyampaikan keluhan dalam kegiatan pembelajaran secara daring yang dilakukan siswa di rumah mengalami beberapa kendala, yaitu siswa merasa bosan dan jenuh.

\section{Hasil dan Pembahasan}

\section{A. Hasil}

Kegiatan pengabdian masyarakat untuk guru-guru MGMP Fisika Kabupaten Lebak telah dilaksanakan dengan baik meskipun secara virtual melalui zoom pada hari Jum'at, 08 November 2020.

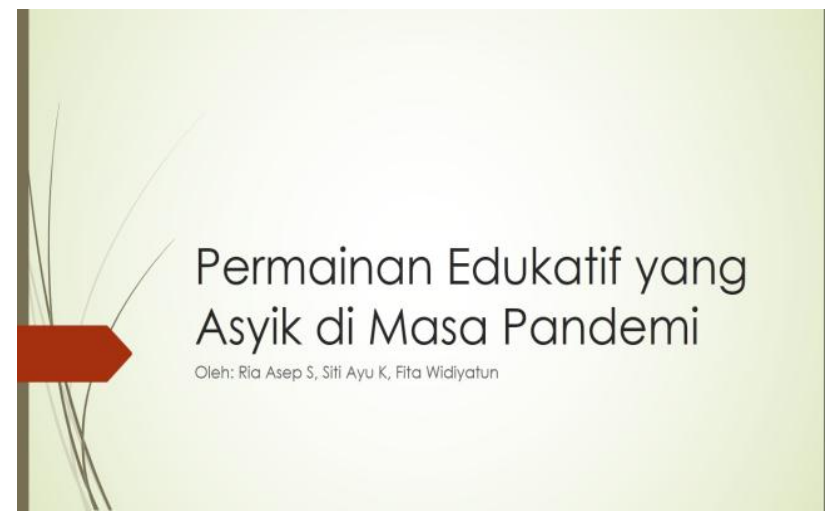

Gambar 2. Tampilan Slide Materi yang disampaikan

Tim yang menyampaikan materi ini diwakilkan oleh Ria Asep Sumarni selaku ketua tim pengabdian kepada masyarakat untuk tema permainan edukatif ini. Adapun materi-materi yang dibahas pada pelatihan ini yaitu tentang media pembelajaran menggunakan permainan kartu domino fisika dan Uno Stacko fisika. Adapun materi yang kami buat berdasarkan materi yaitu sebagai berikut:

\section{Kartu Domino Fisika}

Pembuatan kartu domino fisika yaitu dengan mengganti lingkaran pada kartu domino dengan materi fisika. Tatacara permaian kartu domino fisika hampir sama dengan permaian domino pada umumnya, yaitu menyatukan besaran dan satuan yang sama. Sebagai contoh, untuk besaran masa, maka pasangannya adalah satuan-satuannya, yaitu ton, kwintal, ons, dan gram. Permaian ini akan berakhir apabila kartu yang dimiliki oleh masing-masing peserta tidak ada yang mempunyai pasangan dari besaran ataupun satuannya. Serta pemenang dari permaian 
ini adalah yang berhasil lebih dulu menghabiskan kartu yang dimiliknya dari pada temantemannya, atau paling sedikit kartu yang dimiliki.

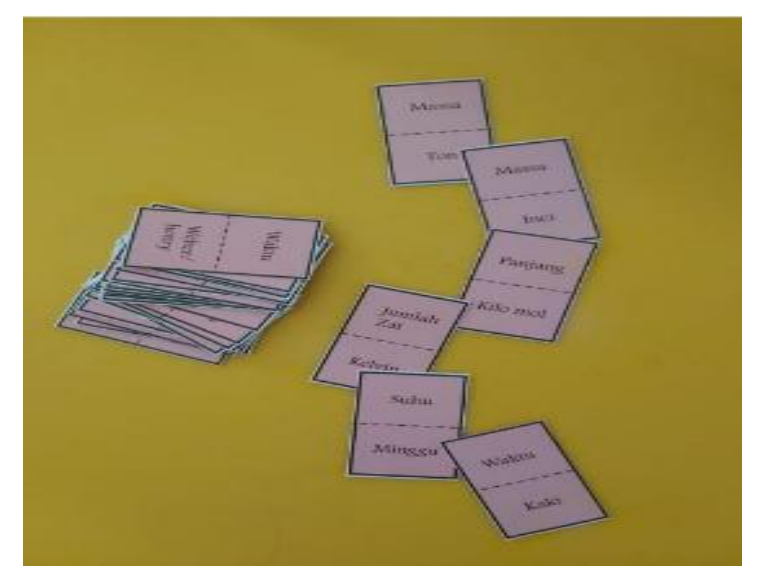

Gambar 3. Visualisasi permainan kartu domino fisika

\section{Permainan Uno Stacko Fisika}

Sebenarnya, permainan memiliki nama asli Jenga, yaitu sebuah permainan dengan cara mengambil balok yang berada di tumpukan bawah atau tengah dan kemudian menaruhnya di tumpukan yang terletak paling atas tanpa menjatuhkan balok-balok yang lain. Pada dasarnya penggunaan media pembelajaran fisika Uno Stacko sama dengan aturan main Uno Stacko pada umumnya, namun dengan beberapa modifikasi.

Rancangan pembuatan alat media pembelajaran memerlukan bahan sebagai berikut: dua set Uno Stacko, kertas print soal, isolasi, kertas bufallo, gunting dan spidol permanen. Tahap pertama dalam pembuatan permainan edukatif ini dengan menggunakan Uno Stacko adalah dengan menentukan letak yang tepat dalam pemasangan soal pada balok Uno Stacko. Selain menentukan lekat pemasangan soal, guru juga perlu memperhatikan ukuran huruf pada soal supaya tetap terbaca jelas pada saat dipasang di balok Uno Stacko

Balok-balok Uno Stacko ditempel dengan soal materi fisika. Materi-materi tersebut meliputi besaran dan satuan, vektor, kinematika, dinamika, usaha dan energi, momentum dan impuls serta tumbukan.Pada masing masing balok sisi satunya ditempel dengan soal dan sisi lainnya ditempel skor nilai dari soal tersebut. Pembahasan dan jawaban soal dibuat terpisah dicetak dikertas selembar dari kertas bufallo, untuk mencocokkan jawaban benar atau salah. Media pembelajaran menggunakan permainan Uno Stacko ini juga dilengkapi panduan yang memudahkan bagi pengguna untuk memahami aturan main media ini.

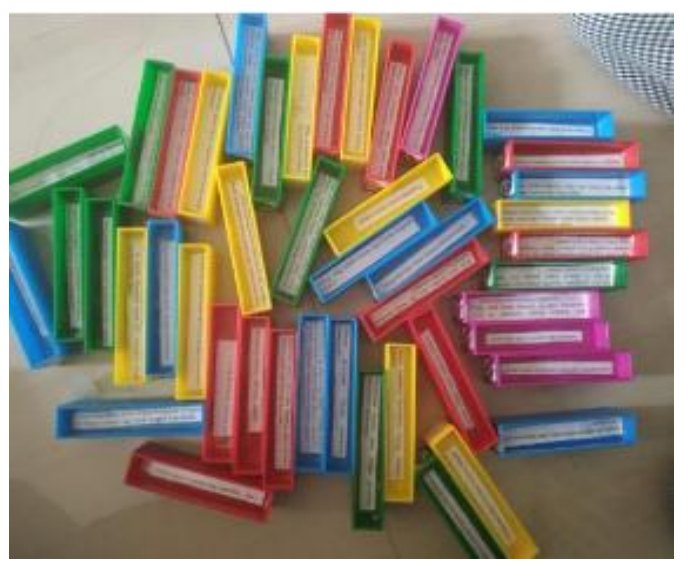

Gambar 4. Uno Stacko yang telah ditempeli soal-soal fisika 
Berikut ini merupakan dokumentasi melalui zoom, saat pelaksanaan webinar pengabdian kepada masyarakat Universitas Indraprasta PGRI dengan MGMP Fisika Kabupaten Lebak Banten.

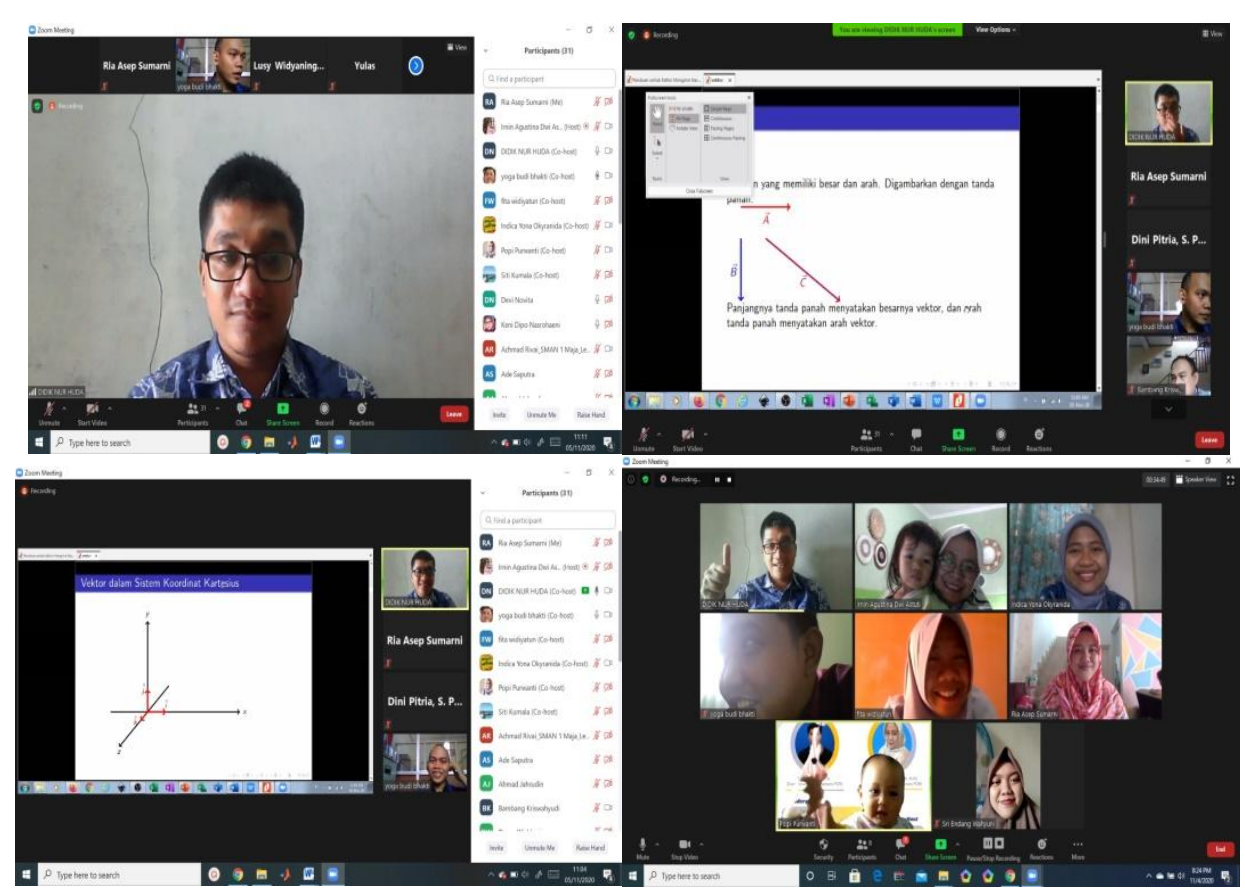

Gambar 5. Screenshoot Zoom Webinar Pengabdian Kepada Masyarakat

\section{B. Pembahasan}

Selama hampir setahun guru-guru fisika di berbagai daerah melaksanakan pembelajaran jarak jauh atau daring akibat pandemi Covid 19 yang mengharuskan siswa belajar dari rumah. Siswa dan guru merasa bosan dengan kegiatan pembelajaran yang monoton setiap hari. Guru memberi materi dalam bentuk word atau pdf kemudian memberi tugas yang harus dikerjakan dan dikirim kembali kepada guru dalam jangka waktu tertentu. Untuk itu guru-guru khususnya guru-guru fisika dituntut untuk selalu berinovasi menciptakan pembelajaran jarak jauh yang lebih menarik dan interaktif. Oleh karena itu, permainan edukatif bisa membantu guru dan siswa agar pembelajaran di rumah terasa lebih menyenangkan.

Kegiatan abdimas ini dilaksanakan dengan MGMP Fisika Kabupaten Lebak Banten. Kegiatan ini dapat terlaksana dengan lancar, peserta kegiatan terdiri dari 27 orang guru-guru fisika dari berbagai sekolah di Kabupaten Lebak serta 1 orang yang berasal dari Universitas Terbuka (UT). Para peserta sangat antusias dalam mendengarkan dan bertanya kepada pemateri tentang materi yang diberikan. Guru diberikan sosialisasi tentang permainan edukatif yang mudah untuk dibuat dan digunakan dalam pembelajaran. Setelah diberikan contoh tentang media pembelajaran edukatif berupa permainan kartu domino dan uno, guru diberikan kesempatan untuk mencari ide membuat media pembelajaran lain. Guru sangat antusias dalam mencoba menyampaikan ide permainan edukatif untuk pembelajaran, beberapa juga melakukan diskusi untuk melakukan kolaborasi dalam pembuatan permainan edukatif tersebut. 


\section{Simpulan}

Kegiatan PKM yang berjudul "Permainan Edukatif yang Asyik di Masa Pandemi" bagi Guru-guru fisika MGMP Kabupaten Lebak Banten pelatihan ini telah dilaksanakan dengan baik meskipun secara daring. Para peserta ingin menerapkan media pembelajaran serta permainan yang sudah disampaikan pemateri. Hal ini dikerenakan ilmu yang mereka sudah didapatkan tidak sia-sia dan langsung dipraktekan di sekolah, walau masih dalam proses jika dilakukan setiap saat maka akan semakin terbiasa. Dalam kegiatan ini peserta yang hadir ada 27 orang yang berasal dari sekolah-sekolah di Kabupaten Lebak. Selain itu, kegiatan ini memberikan kesempatan berkreativitas bagi guru-guru lainnya. Dengan mengembangkan skill para guru di sekolah tidak hanya bisa mengajar seperti biasa tapi juga bisa membuat siswa lebih tertarik dan tidak membosankan dengan berbagai variassi media pembelajaran dan permainan edukatif. Dari hasil evaluasi akhir, dapat diambil simpulan bahwa peserta dapat mengikuti kegiatan dengan baik dan mendapatkan pembekalan berupa media pembelajaran yang asyik dengan menggunakan permainan kartu domino dan Uno Stacko.

\section{Ucapan Terima Kasih}

Tim pengabdian mengucapkan terima kasih kepada berbagai pihak yang aktif terlibat dalam kegiatan ini sehingga kegiatan ini dapat terlaksana dengan baik dan lancar. Ucapan terima kasih sebesar-besarnya kami sampaikan kepada pihak MGMP Fisika Kabupaten Lebak Banten yang telah membantu terlaksananya kegiatan ini.

\section{Daftar Pustaka}

Azmi, R. A., \& Rukun, K. (2020). Analisis Kebutuhan Pengembangan Media Pembelajaran Berbasis Web Mata Pelajaran Administrasi Infrastruktur Jaringan. Jurnal Imiah Pendidikan Dan Pembelajaran, 303-314. https://ejournal.undiksha.ac.id/index.php/JIPP/article/view/25840/15852

Fadli, A., Suharto, \& Musadad, A. A. (2017). Prosiding Seminar Pendidikan Nasional Deskripsi Analisis Kebutuhan Media Pembelajaran Berbasis Role Play Game Education untuk Pembelajaran Matematika Prosiding Seminar Pendidikan Nasional. Prosiding Seminar Pendidikan Nasional, 1, 52-57.

Fairosa, S., Prayekti, N., \& Hariastuti, R. M. (2018). Pengembangan Media Permainan Matematika Berbasis Kartu Domino Pada Materi Eksponen. TRANSFORMASI-Jurnal

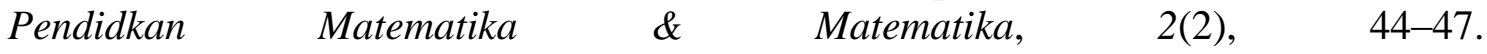
https://doi.org/10.1515/9783111634487-006

Gustiasih, F., \& Widajati, W. (2016). Pengaruh Model Pembelajaran Konstruktivistik Bermedia Uno Stacko Terhadap Kemampuan Mengenal Lambang Bilangan Anak Kelompok A. PAUD Teratai, Vol 5(2), 1-6.

Jayanti, E., \& Azmi, J. (n.d.). Use of Domino Card Game Media To Improve Student Achievement on Subject of Oxsidation Reduction Reaction in Class X Sma Negeri 10 Pekanbaru Pada Pokok Bahasan Reaksi Reduksi Oksidasi. 1-10.

Nugroho, A., Raharjo, T., \& Wahyuningsih, D. (2013). Pengembangan Media Pembelajaran Fisika Menggunakan Permainan Ular Tangga Ditinjau Dari Motivasi Belajar Siswa Kelas Viii Materi Gaya. Jurnal Pendidikan Fisika, 1(1), 11-18.

Putri, A. R. S., \& Airlanda, G. S. (2020). Pengembangan Media Pembelajaran Game PEKA Untuk Meningkatkan Hasil Belajar Kognitif Peserta Didik Pada Materi Pecahan. Efektor, 
7(2), 109-116. https://doi.org/10.29407/e.v7i2.14978

Ramadhani, N., Wahyuni, S., \& Handayani, R. (2016). Pengembangan Media Educational Game "Monopoli Fisika Asik (Mosik)" Pada Mata Pelajaran IPA Di SMP. Jurnal Pembelajaran Fisika Universitas Jember, 5(3), 235-245.

Widiyatun, F., Sumarni, R. A., \& Kumala, S. A. (2020). Pengembangan dan Validasi Kartu Domino Besan (Besaran dan Satuan). Prosiding Seminar Nasional Sains, 1(1), 58-64.

Wiyono, K. E., Sudjito, D. N., \& Rondonuwu, F. S. (2020). Pengembangan Media Kartu Domino Fisika (Domika) Untuk Meningkatkan Minat Belajar Pada Materi Kinematika Gerak. Jurnal Pendidikan Fisika, 8(1), 1-8. 